\title{
Improving, Restoring, and Managing Natural Resources on Rural Properties in Florida: Sources of Financial Assistance ${ }^{1}$
}

\author{
Chris Demers, Martin B. Main and Mark E. Hostetler ${ }^{2}$
}

Interested in conserving natural resources, such as wildlife habitat, on your land? Federal and state governments have several programs to respond to a broad range of natural resource challenges faced by landowners. These programs help landowners to reduce soil erosion, protect wetlands and wildlife habitat, and promote forest and farmland productivity and protection. These challenges are addressed through land rentals, technical assistance, cost-shares, and incentive payments.

At the federal level, the 2008 Farm Bill included a number of provisions and incentives for helping landowners to protect and enhance natural resources. At the state level, the Florida Fish and Wildlife Conservation Commission (FWC) and U.S. Fish and Wildlife Service (USFWS) are partnering to provide the Landowner Incentive Program. Emphasis is on improving habitat for listed species or species at risk. The USFWS also administers the Partners for Fish and Wildlife Program at the state level to help landowners improve or restore unique habitats. The purpose of this publication is to inform landowners about government programs available to help conserve natural resources.

Additional information regarding conservation and assistance for management of natural resources in Florida is available on the University of Florida IFAS, Cooperative Extension Electronic Data Information Source (EDIS):

- Paying Private Landowners to Conserve Wildlife Habitat: A Unique Approach to Conservation (http://edis.ifas.ufl.edu/UW138)

- Improving, Restoring, and Managing Natural Resources in Florida: Sources of Technical Assistance for Rural Landowners (http://edis.ifas.ufl.edu/UW218)

- Improving, Restoring, and Managing Natural Resources in Florida: Sources of Technical Assistance for Urban Homeowners (http://edis.ifas.ufl.edu/UW212)

1. This document is SS-FOR-23, one of a Forest Stewardship Program series of the School of Forest Resources and Conservation, Florida Cooperative Extension Service, Institute of Food and Agricultural Sciences, University of Florida. First published: February 2006, revised September 2009. Funding for the production of this publication is provided by the USDA Forest Service through the Florida Department of Agriculture and Consumer Services Division of Forestry. Please visit the EDIS website at http://edis.ifas.ufl.edu.

2. Chris Demers, Forest Stewardship Coordinator, University of Florida, School of Forest Resources and Conservation; Martin B. Main, associate professor, University of Florida, Southwest Florida Research and Education Center, Immokalee, FL; Mark E. Hostetler, assistant professor, University of Florida, Wildlife Ecology and Conservation Department, Gainesville, FL.

The Institute of Food and Agricultural Sciences (IFAS) is an Equal Opportunity Institution authorized to provide research, educational information and other services only to individuals and institutions that function with non-discrimination with respect to race, creed, color, religion, age, disability, sex, sexual orientation, marital status, national origin, political opinions or affiliations. U.S. Department of Agriculture, Cooperative Extension Service, University of Florida, IFAS, Florida A. \& M. University Cooperative Extension Program, and Boards of County Commissioners Cooperating. Millie Ferrer-Chancy, Interim Dean 
- Conservation Options for Private Landowners in Florida (http://edis.ifas.ufl.edu/UW194)

- Conservation Easements: Options for Preserving Current Land Uses (http://edis.ifas.ufl.edu/FR149)

- Evaluating Private Lands for Conservation of Wildlife (http://edis.ifas.ufl.edu/FR149)

- Got Invasives? Get Help! (http://edis.ifas.ufl.edu/FR285)

\section{Farm Bill Programs}

\section{Biomass Crop Assistance Program}

The Biomass Crop Assistance Program (BCAP), administered by The U.S. Department of Agriculture (USDA) Farm Service Agency (FSA), is a new program that will provide financial assistance to producers or entities that deliver eligible biomass material to designated biomass conversion facilities for use as heat, power, biobased products or biofuels. Initial assistance will be for the collection, harvest, storage and transportation costs associated with the delivery of eligible materials.

Producers or entities will be eligible for up to a dollar per dollar match, up to $\$ 45$ per dry ton, for the value of the biomass that is delivered to a designated biomass conversion facility. Producers will be eligible for up to two years of payments.

For example: if a producer is paid $\$ 30$ per dry ton for the biomass by the conversion facility, the producer would be eligible for a $\$ 30$ per dry ton payment for the costs associated with collecting, harvesting, transporting and storing the product.

This program is still in development. Details will be available at http://www.fsa.usda.gov/FSA/ webapp?area=home\&subject=ener\&topic=bcap as they are available.

\section{Conservation Reserve Program (CRP)}

The CRP is a voluntary, long-term cropland retirement program. It provides participants (farm owners, operators, or tenants) with an annual per-acre rent plus half the cost of establishing permanent cover (usually grass or trees). In exchange, the participant will not farm on environmentally sensitive cropland for $10-15$ years. Cost-sharing is up to 50 percent of total costs.

\section{How CRP Works}

The USDA Farm Service Agency administers CRP. Payments are provided on a contractual basis to owners. Eligible lands are conserved and improved for soil, water and wildlife. Eligible land includes pastureland devoted to appropriate vegetation, including trees, for enhancing water or soil quality and wildlife habitat. Although limited haying and grazing is permitted, trees planted on land under CRP contract cannot be harvested or commercially sold unless expressly permitted in the contract. Pine straw harvesting is also prohibited under a CRP contract.

\section{Ranking CRP Offers}

Interested landowners must apply to participate in the CRP. Applications for CRP contracts are ranked according to the Environmental Benefits Index (EBI), which evaluates CRP contracts and applications based on the following criteria:

- wildlife habitat benefits resulting from contract acreage;

- water quality benefits from reduced erosion, runoff, and leaching;

- on-farm benefits from reduced erosion;

- benefits that will likely endure beyond the contract period;

- air quality benefits from reduced wind erosion; and

- cost.

\section{Rental and Practice Payments}

Several types of financial incentives are available in CRP contracts:

1. Rental Payments: In return for establishing long-term conservation on private lands, CRP provides annual rental payments to participants. 
CRP bases rental rates on the quality of the soils within your county and the average price paid per acre, in your county, for the crop you are growing. The maximum CRP rental rate for each offer is calculated in advance of enrollment. Producers may offer land at that rate or offer a lower rental rate to increase the likelihood that their offer will be accepted.

2. Maintenance Incentive Payments: CRP annual rental payments may include an additional amount up to $\$ 4$ per acre per year as an incentive to perform certain maintenance obligations. In Florida, this additional payment is commonly for establishing firebreaks around pine stands.

3. Cost-share Assistance: is provided to participants who establish approved cover, such as trees and native grasses, on eligible cropland. The cost-share assistance can be an amount not more than 50 percent of the applicant's costs in establishing approved practices.

4. Other Incentives: CRP may offer additional financial incentives of up to 20 percent of the annual payment for certain continuous sign-up practices. This would be a one-time payment for certain practices that are approved after the contract begins. Examples of these include, but are not limited to: riparian buffer establishment, wind break establishment, farmable wetland practices, wetland buffers, wildlife habitat buffers and wetland restoration.

\section{Eligibility}

To be eligible for CRP enrollment, a producer must have owned or operated the land for at least 1 year prior to the end of the CRP sign-up period. Eligible land must be either:

- cropland (including field margins) that is planted or considered planted to an agricultural commodity 4 of the previous 6 crop years from 1996 to 2001, and which is physically and legally capable of being planted to an agricultural commodity; or

- marginal pastureland that is enrolled in the Water Bank Program ( http://www.federalgrantswire.com/water-bankprogram.html) or suitable for use as a riparian buffer or for similar water quality purposes. A riparian buffer is land situated along a river or creek.

In addition to the eligible land requirements, cropland must meet one of the following criteria:

- have a weighted average erosion index of 8 or higher;

- be acreage that is not currently under a CRP contract; or

- be located in a national or state CRP conservation priority area.

\section{How to Apply}

General CRP sign-up is offered only during designated sign-up periods. For information on upcoming sign-ups, contact your local USDA Service Center, listed in the telephone book under U.S. Department of Agriculture, or on the internet at http://offices.sc.egov.usda.gov/locator/app.

In addition to the general CRP sign-up period, environmentally desirable land devoted to certain conservation practices may be enrolled at any time. Certain eligibility requirements still apply, but offers are not subject to competitive bidding. USDA representatives determine if the land is environmentally desirable. Contact your local USDA Service Center to see if you qualify.

For more information on CRP, contact your local FSA office or visit FSA's website at: http://www.fsa.usda.gov/FSA/ webapp?area=home\&subject=copr \& topic=crp.

\section{Conservation Stewardship Program}

The Conservation Stewardship Program (CSP) is a voluntary conservation program that encourages producers to address resource concerns by undertaking additional conservation activities and improving, maintaining, and managing existing conservation activities. 
Through CSP, NRCS will provide financial and technical assistance to eligible producers to conserve and enhance soil, water, air, and related natural resources on their land.

\section{Practice Payments}

CSP provides participants with two possible types of payments:

1. An annual payment is available for installing new conservation activities and maintaining existing activities.

\section{A supplemental payment may be earned by} participants receiving an annual payment who also adopt a resource-conserving crop rotation.

Through 5-year contracts, payments will be made as soon as practical after October of each year for contract activities installed and maintained in the previous year. For all contracts, CSP payments to a person or legal entity may not exceed $\$ 40,000$ in any year, and \$200,000 during any 5-year period. Each CSP contract will be limited to $\$ 200,000$ over the term of the initial contract period.

\section{Eligibility}

Eligible lands include cropland, grassland, prairie land, improved pastureland, rangeland, nonindustrial private forest lands, agricultural land under the jurisdiction of an Indian tribe, and other private agricultural land (including cropped woodland, marshes, and agricultural land used for the production of livestock) on which resource concerns related to agricultural production could be addressed.

\section{How to Apply}

Producers interested in CSP are encouraged to begin the application process by completing a producer self-screening checklist. The self-screening checklist helps potential applicants decide for themselves whether CSP is the right program for them. The level of environmental benefit to be achieved will be estimated to determine eligibility, rank applications, and establish payments. For a pre-approved applicant, NRCS will request the applicant's conservation activity records and conduct on-site field verification to ensure that information provided by the applicant was accurate prior to contract approval. Once information is verified, NRCS and the applicant proceed to develop the contract.

For more information on CSP, visit http://www.nrcs.usda.gov/programs/new_csp/ csp.html.

\section{Environmental Quality Incentives Program (EQIP)}

The Environmental Quality Incentives Program (EQIP) is a voluntary conservation program that provides financial and technical assistance to farmers and ranchers who face threats to soil, water, air, and related natural resources on their land. Through EQIP, the USDA Natural Resources Conservation Service (NRCS) develops contracts with agricultural producers to implement conservation practices to address environmental natural resource problems. Payments are made to producers once conservation practices are completed according to NRCS requirements.

\section{How EQIP Works}

EQIP optimizes environmental benefits based on National priorities addressing:

- impaired water quality;

- conservation of ground and surface water resources;

- improvement of air quality;

- reduction of soil erosion and sedimentation; and

- improvement or creation of wildlife habitat for at-risk species.

NRCS state conservationists identify priority natural resource concerns to guide their decisions about which applicants are awarded assistance. The state conservationist, with advice from a state technical committee, decides how funds will be allocated. The local designated conservationist, with the advice of local work groups, adapts the state program to the local conditions. As a result, EQIP 
can be different between states and even between counties.

Applications for EQIP are ranked based on the environmental benefits and costs. More information regarding state and local EQIP implementation can be found at http://www.nrcs.usda.gov/programs/eqip/.

\section{Practice Payments}

Cost-sharing may pay up to 75 percent of the costs of conservation practices. The EQIP cost-share rates for limited resource producers and beginning farmers and ranchers may be up to 90 percent. Cost-share funds are also available for organic agriculture. The 2008 Farm Bill limits the total amount of cost-share and incentive payments paid to an individual or entity to an aggregate of $\$ 300,000$ for all contracts entered into during any 6-year period. This sum applies to all contracts entered into during fiscal years 2009 through 2014 .

\section{EQIP Organic Initiative}

The new EQIP Organic Initiative helps certified organic producers and those transitioning to organic production to implement new conservation practices on their land that will help solve an identified resource problem. The "Core 6 Practices" include conservation crop rotation, cover crops, nutrient management, pest management and prescribed grazing. These

applications will be ranked and funded from a special funding pool for organic producers and will be competing only against others in this special pool for funding. This Organic Initiative does not offer financial incentives for the production of organic products or for the transition from conventional agricultural production to organic production. The initiative allows producers to receive up to $\$ 20,000$ per year or $\$ 80,000$ over six years. EQIP payments are set up by a contract that can last over several years. More information available at: http://ofrf.org/policy/federal_legislation/ farm_bill_implementation/ eqip_oi_resource_page.html

\section{Eligibility}

Eligible land includes cropland, rangeland, pastureland, private non-industrial forestland, and other farm or ranch lands. Those interested in entering into a cost-share agreement with the USDA for EQIP assistance may file an application at any time. Applicants must:

- be an agricultural producer;

- be in compliance with the highly erodible land and wetland conservation provisions of the Farm Bill; and

- develop an EQIP plan of operations, including:

- the participant's conservation and environmental objectives to be achieved;

- one or more conservation practices in the conservation management system to be implemented to achieve the conservation and environmental objectives; and

- the schedule for implementing the conservation practices.

If an EQIP contract includes an animal waste storage or treatment facility, the participant must implement a comprehensive nutrient management plan (CNMP). If an EQIP plan addresses non-industrial private forestland, the participant must implement a forest management plan.

\section{How to Apply}

Applications may be obtained and filed at any time with your local USDA Service Center or conservation district office. Applications also may be obtained through USDA's e-gov website:

http://www.sc.egov.usda.gov.

For more information about EQIP, contact your local USDA Service Center, listed in the telephone book under U.S. Department of Agriculture, or on the internet at http://offices.sc.egov.usda.gov/locator/app. Information also is available on the Web at: http://www.nrcs.usda.gov/programs/farmbill/2008/.

\section{Grasslands Reserve Program}

The Grassland Reserve Program (GRP) helps landowners and operators restore and protect grassland while maintaining the areas as grazing 
lands. The program emphasizes support for grazing operations, plant and animal biodiversity, and land that contains shrubs and forbs and that faces threat of conversion to other land uses.

\section{Enrollment Options}

The program offers these enrollment options:

1. Permanent Easement. This is a conservation easement in perpetuity. Payments for this option equal the fair market value, less the grazing value of the land encumbered by the easement. These values will be determined using an appraisal. FSA or NRCS will cover all administrative costs associated with recording the easement. This includes appraisal fees, survey costs, title insurance and recording fees. Easement payments may be provided, at the participant's request, in lump sum or annual payments (equal or unequal amounts) for up to 10 years.

\section{Rental Agreement. Participants may choose a} 10-year, 15-year or 20-year contract. FSA or NRCS will provide annual payments in an amount that is not more than 75 percent of the grazing value of the land covered by the agreement for the life of the agreement. Payments will not exceed $\$ 50,000$ per person or legal entity and will be disbursed annually.

\section{Restoration agreement. Certain grassland} easements or rental contracts may be eligible for cost-share assistance covering up to 50 percent of the cost to re-establish grassland functions and values where the land has been degraded or converted to other uses. Participants may contribute to the application of a cost-share practice through in-kind contributions. Payments will not exceed $\$ 50,000$ per year per person or legal entity.

Applications may be filed for an easement or rental agreement with NRCS or FSA at any time. Participants voluntarily limit future use of the land while retaining the right to conduct:

- common grazing practices;
- hay production, mowing, or harvesting for seed production (subject to certain restrictions during the nesting season of bird species that are in significant decline or those that are protected under federal or state law, see http://www.fws.gov/endangered/;

- fire rehabilitation; and

- firebreak and fence construction.

\section{Eligibility}

Landowners who can provide clear title to their land are eligible to participate in either easement option. The Adjusted Gross Income (AGI) provision of the 2008 Farm Bill impacts eligibility for GRP and several other Farm Bill programs. Individuals or entities that have an average adjusted gross nonfarm income exceeding \$1 million for the three tax years immediately preceding the year the contract is approved are not eligible to receive program benefits or payments. However, an exemption is provided in cases where two-thirds of the adjusted gross income is derived from farming, ranching, or forestry operations.

Eligible land includes grassland or land that contains forbs or shrubs (including improved rangeland and pastureland), grassland or land that historically has been dominated by grassland, forbs, and shrubs and has potential to provide habitat for animal or plant populations of significant ecological value.

\section{For More Information}

For more information about GRP, including application procedures, contact your local USDA Service Center, listed in the telephone book under U.S. Department of Agriculture or on the internet at http://offices.sc.egov.usda.gov/locator/app. Information also is available on the Web at: http://www.nrcs.usda.gov/programs/GRP/ and http://www.nrcs.usda.gov/programs/farmbill/2008/.

\section{Healthy Forests Reserve Program}

The Healthy Forests Reserve Program (HFRP) was established to restore and enhance forest ecosystems to: 1) promote the recovery of threatened 
and endangered species, 2) improve biodiversity; and 3) enhance carbon sequestration.

Landowner Protections will be made available to landowners enrolled in the HFRP who agree, for a specified period, to restore or improve their land for threatened or endangered species habitat. In exchange, they avoid future regulatory restrictions under the Endangered Species Act.

\section{Enrollment Options}

The Program offers three enrollment options:

1. A 10-year cost-share agreement: the landowner may receive 50 percent of the average cost of the approved conservation practices,

2. A 30-year easement: the landowner may receive 75 percent of the easement value of the enrolled land plus 75 percent of the average cost of the approved conservation practices, or

3. An easement of not more than 99 years: the landowner may receive 100 percent of the easement value of the enrolled land plus 100 percent of the average cost of the approved conservation practices.

\section{Eligibility}

To be eligible for enrollment, land must be private land or tribal lands which will restore, enhance, or measurably increase the likelihood of recovery of a threatened or endangered species; and must improve biological diversity or increase carbon sequestration.

For more information about HFRP, contact your local USDA Service Center, listed in the telephone book under U.S. Department of Agriculture or on the internet at http://offices.sc.egov.usda.gov/locator/app. Also see http://www.nrcs.usda.gov/programs/HFRP/ProgInfo/ Index.html.

\section{Wetlands Reserve Program}

Administered by NRCS, the Wetlands Reserve Program (WRP) provides technical and financial assistance to address wetland, wildlife habitat, soil, water, and related natural resource concerns on private lands. The program provides landowners financial incentives to enhance wetlands in exchange for retiring marginal land from agriculture.

\section{Enrollment Options}

Landowners and Tribes may file an application for a conservation easement or a cost-share restoration agreement with the NRCS to restore and protect wetlands. Participants voluntarily limit future use of the land, but retain private ownership.

The program offers three enrollment options:

1. Permanent Easement. This is a conservation easement in perpetuity. Easement payments equal the lowest of three amounts: the agricultural value of the land, an established payment cap, or an amount offered by the landowner. In addition to paying for the easement, NRCS pays 100 percent of the costs of restoring the wetland.

\section{30-Year Easement. Easement payments} through this option are 75 percent of what would be paid for a permanent easement. NRCS also can pay 75 percent of restoration costs.

For both permanent and 30-year easements, NRCS pays all costs associated with recording the easement in the local land records office, including recording fees, charges for abstracts, survey and appraisal fees, and title insurance.

3. Restoration Cost-Share Agreement. This is an agreement, generally for a minimum of 10 years, to restore degraded or lost wetland habitat. NRCS can pay 75 percent of the cost of the restoration activity. This enrollment option does not place an easement on the property. Other agencies, conservation districts, and private conservation organizations may provide additional financial assistance. Such special partnership efforts are encouraged.

NRCS and its partners, including conservation districts, will continue to provide assistance to landowners after completion of restoration activities. This assistance may be in the form of reviewing restoration measures, clarifying technical and administrative aspects of the easement and project management needs, and providing basic biological 
and engineering advice on how to successfully establish wetland species.

\section{Eligibility}

To offer a conservation easement, the landowner must have owned the land for at least 12 months prior to enrolling it in the program and must show evidence of ownership. To be eligible for WRP, land must be restorable and be suitable for wildlife benefits. This includes:

- wetlands farmed under natural conditions;

- prior converted cropland;

- farmed wetland pasture;

- farmland that has become a wetland as a result of flooding;

- range land, pasture, or production forestland where the hydrology has been significantly degraded and can be restored;

- riparian areas which link protected wetlands;

- lands adjacent to protected wetlands that contribute significantly to wetland functions and values; and

- previously restored wetlands that need long-term protection.

Ineligible land includes:

- wetlands converted after December 23, 1985;

- lands with timber stands established under a Conservation Reserve Program contract;

- federal lands; and

- lands where conditions make restoration impossible.

\section{Uses of WRP Land}

On acreage with a WRP easement, participants control access to the land and may lease the land for hunting, fishing, and other undeveloped recreational activities. At any time a participant may request that additional activities be evaluated. This request may include such items as permission to cut hay, graze livestock, or harvest wood products. Compatible uses are allowed if they are fully consistent with the protection and enhancement of the wetland. A new Reserved Rights Pilot Program allows landowners to retain grazing rights under a WRP contract.

\section{How to Apply}

Applications are accepted through a continuous sign-up process. Applications may be obtained and filed at any time with your local USDA Service Center or conservation district office. Applications can also be found on USDA's e-gov website at: http://www.sc.egov.usda.gov.

If you need more information about WRP, please contact your local USDA Service Center, listed in the telephone book under U.S. Department of Agriculture or on the internet at http://offices.sc.egov.usda.gov/locator/app. Information is also available on the Web at: http://www.nrcs.usda.gov/programs/wrp/ and http://www.nrcs.usda.gov/programs/farmbill/2008/.

\section{Wildlife Habitat Incentives Program (WHIP)}

The Wildlife Habitat Incentive Program provides cost-share incentives for the development, enhancement, and restoration of habitat for both game and nongame wildlife species, on all land uses. An emphasis is placed on projects which improve conditions for species in decline or enhance or restore imperiled ecosystems. Through a cooperative effort, the NRCS, the USFWS and the FWC provide technical assistance in the planning and application phases of eligible practices. Also, if the landowner agrees, private, nonprofit organizations may provide assistance or additional funding to help complete the project.

NRCS has established the following national priorities to provide direction to state and local conservationists for implementing WHIP:

- promote the restoration of declining or important native fish and wildlife habitats; 
- protect, restore, develop or enhance fish and wildlife habitat to benefit at-risk species;

- reduce the impacts of invasive species on fish and wildlife habitats; and

- protect, restore, develop or enhance declining or important aquatic wildlife species' habitats.

In addition to technical assistance, the USDA will pay up to 75 percent of the state average installation cost of approved wildlife habitat management practices. The maximum total cost-share is $\$ 50,000$ per year for the length of the contract period. Cost-share payments may be used to establish new management practices or replace ineffective management practices. WHIP funds cannot be used for mitigation or on land designated as converted wetland.

\section{Practices Offered and Contract Life Span}

WHIP provides funding for wildlife habitat development and maintenance, brush management, prescribed burning, creation of wildlife openings and improvements to fish streams. Cost-share agreements between NRCS and the participant are for a minimum of 1 year after completion of the last conservation practice, up to 10 years.

Up to 25 percent of WHIP funds will be available for long-term cost-share agreements (15 years or longer) to protect and restore essential plant and animal habitat. NRCS can pay up to 90 percent of the cost to install conservation practices in these long-term agreements. Essential plant and animal habitat includes critical habitat designated under federal and state law, locations of listed or candidate species that can be improved with specific conservation practices, or particularly rare and unique habitats that could support at-risk wildlife species.

\section{Eligibility}

Land eligible for WHIP includes:

- private agricultural land including cropland, grassland, rangeland, pasture, and other land determined by NRCS to be suitable for fish and wildlife habitat development;
- non-industrial private forest land including rural land that has existing tree cover or is suitable for growing trees; and

- tribal land.

Increased cost-share payments are available for eligible socially disadvantaged farmers or ranchers in addition to beginning and limited resource farmers or ranchers and indian tribes.

\section{How to Apply}

Applications are accepted through a continuous sign-up process. Applications may be obtained and filed at any time with your local USDA Service Center or conservation district office. Applications also may be obtained through Florida NRCS's website at http://www.fl.nrcs.usda.gov/.

For more information about WHIP, contact your local USDA Service Center, listed in the telephone book under U.S. Department of Agriculture or on the internet at http://offices.sc.egov.usda.gov/locator/app. Information is also available on the Web at http://www.nrcs.usda.gov/programs/whip/.

\section{Other Assistance}

\section{Landowner Incentives Program}

The Florida Fish and Wildlife Conservation Commission is cooperating with the U.S. Fish and Wildlife Service to implement a new private landowner assistance program called the Landowner Incentives Program (LIP). Florida's LIP is a voluntary program designed to provide technical and financial support to those private landowners interested in improving habitat conditions on their properties for species at risk. Cost-shares require a 50 percent non-federal match and are reimbursed based on established flat rates for each approved practice.

\section{How to Apply}

Applications will be accepted continuously. FWC biologists conduct needs assessments on the highest ranked properties and recommend appropriate and beneficial practices to landowners based on the application evaluation and site visit. 
Landowners have twelve months to complete approved wildlife management practices. Six-month extensions may be approved on a case-by-case basis. Landowners will be reimbursed for approved practices completed and reviewed by a FWC biologist. To receive reimbursement, landowners must complete the approved practice as specified in the practice standards and must submit invoices and/or documentation supporting total expenditures for each practice.

For an application or more information on the Landowner Incentive Program, visit the

Commission's LIP website at http://myfwc.com/CONSERVATION/ ConservationYou_LAP_index.htm or contact the LIP Coordinator at (850) 488-3831.

\section{Partners for Fish and Wildlife Program}

Administered by the USFWS, the Partners for Fish and Wildlife program is a voluntary private lands initiative developed to provide technical and financial assistance to private landowners and other partners who conduct habitat restoration and improvement activities on their land. The focus of the Partners Program in Florida is on restoration of native habitats (i.e., longleaf pine sandhill, scrub), restoration of degraded streams and wetlands, and eradication of invasive, exotic species. The Partners Program also provides technical assistance to the USDA and landowners participating in USDA Farm Bill conservation programs.

For more information about and state contacts for the Partners for Fish and Wildlife Program, see the website at http://www.fws.gov/partners/.

\section{Florida Invasive Species Partnership}

The Florida Invasive Species Partnership (FISP) is a collaboration of federal, state and local agencies along with nongovernment organizations in Florida, formed to link efforts at preventing and controlling infestations of invasive exotic plants across agency and property boundaries. The Florida Invasive Species Partnership has created FloridaInvasives.org to help connect Florida's land owners and land managers with available technical and/or financial assistance programs to prevent or control invasive exotic species problems. These programs have been collected, evaluated and categorized in a single resource to make it easier for landowners and managers to find available financial and/or technical assistance. Visit http://FloridaInvasives.org and click on "Landowner Assistance" to access this resource.

\section{References}

Koubek, B. and C. Demers. 2009. Got Invasives? Get Help! Cooperative Extension Service, University of Florida, Institute of Food and Agricultural Sciences. $1 \mathrm{p}$.

USDA. 2006. Conservation Reserve Program Continuous Sign-up Fact Sheet. USDA Farm Service Agency. 2 p.

USDA. 2009. Farm Bill 2008: Environmental Quality Incentives Program Fact Sheet. USDA Natural Resources Conservation Service. 3 p.

USDA. 2009. Farm Bill 2008: Conservation Stewardship Program. Fact Sheet. USDA Natural Resources Conservation Service. 2 p.

USDA. 2009. Farm Bill 2008: Grassland Reserve Program Fact Sheet. USDA Natural Resources Conservation Service. 2 p.

USDA. 2007. Farm Bill 2002: Wetlands Reserve Program Fact Sheet. USDA Natural Resources Conservation Service. 3 p.

USDA. 2009. Farm Bill 2008: Wildlife Habitat Incentives Program Fact Sheet. USDA Natural Resources Conservation Service. 2 p.

USDI. 2006. Partners for Fish and Wildlife - Florida. USDI Fish and Wildlife Service. 6 p.

Wynn, C. 2004. Florida Landowner Incentive Program. The Florida Forest Steward, vol. 10, no. 4, Forest Stewardship Publication, Florida Cooperative Extension Service, IFAS, University of Florida. Gainesville. 